\title{
pH DAN KAPASITAS BUFFER SALIVA DALAM HUBUNGANNYA TERHADAP PEMBENTUKAN KALKULUS PADA PASIEN DI INSTALASI PERIODONSIA RSGM USU
}

\author{
(SALIVARY pH AND BUFFER CAPACITY RELATED TO CALCULUS \\ FORMATION OF PATIENTS AT PERIODONTICS \\ INSTALLATION IN USU DENTAL HOSPITAL)
}

\author{
Pitu Wulandari, Fellicia Lestari \\ Departemen Periodonsia \\ Fakultas Kedokteran Gigi, Universitas Sumatera Utara \\ Jl. Alumni No. 2 Kampus USU Medan 20155
}

\begin{abstract}
Dental calculus is mineralized dental plaque which composed of inorganic and organic components. Calculus forms on the surfaces of natural teeth and cannot be removed by conventional tooth brushing. Calculus is a common problem for all age groups. It is also an etiological local factor that causes periodontal diseases. One of many factors that influences the formation of calculus is saliva. $\mathrm{pH}$ and buffer capacity of saliva can influence dental calculus formations. Previous studies have shown that salivary $\mathrm{pH}$ and buffer capacity have a major role in calculus formation. The purpose of this study was to analyze the influence of salivary $\mathrm{pH}$ and buffer capacity on calculus formation. This study was an observational analytic study with cross sectional approach. The samples of this study were patients who visited Periodontics Installation in USU Dental Hospital. This study began with collecting stimulated saliva using wax gum with spitting method and continued with oral examination using Oral Calculus Simplified, Volpe Manhold and Periodontal Disease Index. Research results showed positive and significant correlation between salivary $\mathrm{pH}$ and buffer capacity on calculus and periodontal indexes $(\mathrm{p}<0.05)$. In conclusion, salivary $\mathrm{pH}$ and buffer capacity had significant influence of the calculus formation.
\end{abstract}

Key words: calculus, saliva, periodontal disease

\begin{abstract}
Abstrak
Kalkulus adalah plak termineralisasi yang terdiri atas komponen anorganik dan matriks organik. Kalkulus dapat terbentuk dan melekat erat pada permukaan gigi serta tidak dapat dibersihkan dengan penyikatan gigi konvensional. Kalkulus merupakan masalah yang umum bagi semua kalangan usia. Kalkulus juga merupakan salah satu faktor etiologi lokal yang berperan dalam penyakit periodontal. Salah satu hal yang berpengaruh terhadap pembentukan kalkulus adalah saliva. $\mathrm{pH}$ dan kapasitas buffer saliva dapat berpengaruh terhadap pembentukan kalkulus. Penelitian sebelumnya menyatakan bahwa $\mathrm{pH}$ dan kapasitas buffer saliva saling berpengaruh terhadap pembentukan kalkulus. Tujuan penelitian ini adalah untuk menganalisis pengaruh $\mathrm{pH}$ dan kapasitas buffer saliva terhadap pembentukan kalkulus. Jenis penelitian ini adalah analitik observasional dengan rancangan penelitian cross sectional. Penelitian ini dilakukan di Instalasi Periodonsia RSGM USU dengan jumlah sampel 40 orang. Sampel pada penelitian ini adalah pasien yang datang berkunjung ke Instalasi Periodonsia RSGM USU. Penelitian ini diawali dengan mengumpulkan saliva yang distimulasi menggunakan permen karet wax dengan metode spitting untuk pemeriksaan $\mathrm{pH}$ dan kapasitas buffer saliva, kemudian dilakukan pemeriksaan jaringan periodontal berupa indeks kalkulus dan indeks periodontal yang terdiri atas pemeriksaan Oral Calculus Index Simplified, Volpe Manhold Index dan Periodontal Disease Index. Hasil penelitian ini menunjukkan ada korelasi yang positif dan signifikan antara $\mathrm{pH}$ dan kapasitas buffer saliva terhadap indeks kalkulus dan indeks periodontal $(\mathrm{p}<0,05)$. Sebagai kesimpulan, $\mathrm{pH}$ dan kapasitas buffer saliva berpengaruh secara signifikan terhadap pembentukan kalkulus.
\end{abstract}

Kata kunci: kalkulus, saliva, penyakit periodontal 


\section{PENDAHULUAN}

Kalkulus adalah plak yang mengalami mineralisasi yang terbentuk dan melekat erat pada permukaan gigi geligi. Plak gigi merupakan perintis terbentuknya kalkulus. Kalkulus terdiri atas komponen inorganik dan matriks organik. ${ }^{1}$

Berdasarkan hubungannya terhadap margin gingiva, kalkulus sendiri terbagi menjadi kalkulus supragingiva dan kalkulus subgingiva. Kalkulus merupakan salah satu faktor etiologi lokal yang berperan dalam penyakit periodontal dan juga merupakan salah satu faktor predisposisi terhadap terjadinya inflamasi gingiva. ${ }^{1}$ Individu dengan akumulasi plak dan kalkulus yang berat dapat menderita gingivitis. ${ }^{2}$ Ryan juga menyatakan bahwa gingivitis adalah inflamasi gingiva yang berkaitan dengan akumulasi plak dan kalkulus dimana gingivitis ini dapat mengalami perkembangan menjadi penyakit yang lebih parah yang dikenal sebagai periodontitis. $^{3}$

Penyakit periodontal adalah suatu keadaan rongga mulut yang sering ditemui pada manusia dan merupakan penyebab terbanyak kehilangan gigi pada orang dewasa. ${ }^{4}$ Carneiro dan Kabulwa menyatakan karies dental dan penyakit periodontal adalah masalah utama rongga mulut yang sering ditemui didunia. Bahkan, penyakit periodontal termasuk ke dalam daftar penyakit yang sering diderita oleh manusia. ${ }^{5}$ Penelitian yang dilakukan di Amerika Serikat pada tahun 2009 sampai 2010 menunjukkan prevalensi periodontitis pada individu yang berusia 30 tahun ke atas adalah sebesar 47,2\%. ${ }^{6}$ Wahyukundari menyatakan bahwa penyakit periodontal menduduki urutan kedua utama yang masih merupakan masalah bagi masyarakat di Indonesia. ${ }^{7}$ Penelitian yang dilakukan oleh Situmorang N di Kota Medan dengan menggunakan Community Periodontal Index Treatment Need (CPITN), prevalensi penyakit periodontal pada semua usia adalah $96,58 \% .{ }^{8}$ Secara umum, penyakit periodontal dibagi menjadi dua, yaitu gingivitis dan periodontitis. ${ }^{9}$

Salah satu hal yang berpengaruh terhadap pembentukan plak dan kalkulus adalah saliva. Saliva merupakan salah satu faktor yang penting untuk menjaga keseimbangan mineral dan kesehatan rongga mulut. ${ }^{10,11}$ Saliva adalah suatu cairan biologis di dalam rongga mulut yang merupakan campuran hasil sekresi kelenjar ludah mayor dan minor. ${ }^{12}$ Komposisi saliva terdiri atas bahan organik, anorganik dan makromolekul. ${ }^{13}$

Berdasarkan teori presipitasi dalam pembentukan kalkulus, kalsifikasi plak menjadi kalkulus dapat terjadi apabila $\mathrm{pH}$ saliva serta konsentrasi ion kalsium dan fosfat cukup tinggi sehingga meng- akibatkan presipitasi garam kalsium fosfat. ${ }^{13} \mathrm{pH}$ saliva tersebut sangat berhubungan dengan kapasitas buffer yang mana buffer mampu untuk menetralkan keadaan yang asam. Oleh karena itu, $\mathrm{pH}$ dan kapasitas buffer saling berpengaruh dalam pembentukan karies dan kalkulus. ${ }^{14}$ Penelitian Mashhadani menyatakan adanya korelasi yang positif antara $\mathrm{pH}$ dan indeks gingiva yaitu berupa peningkatan rerata $\mathrm{pH}$ saliva seiring dengan peningkatan keparahan inflamasi gingiva. ${ }^{11}$

Penelitian Gupta dkk. menyatakan bahwa pH saliva mempunyai pengaruh besar dalam pembentukan kalkulus, sedangkan Ramisetti dkk. menyatakan bahwa $\mathrm{pH}$ saliva memberikan pengaruh yang tidak signifikan terhadap pembentukan kalkulus. ${ }^{15,16}$ Kitasako dkk. dalam penelitiannya menyatakan bahwa penelitian lebih lanjut dibutuhkan untuk menentukan hubungan antara kapasitas buffer seorang individu dengan parameter penyakit periodontal seperti pembentukan kalkulus. ${ }^{17}$ Gopinath dkk. juga menyatakan bahwa banyak keuntungan dapat diperoleh melalui pemeriksaan saliva yang dilakukan oleh dokter gigi seperti mendiagnosis dan mendeteksi suatu masalah secara dini serta meningkatkan kesadaran pasien akan kesehatan gigi. ${ }^{18}$

Berdasarkan teori dan hasil penelitian tersebut, penulis merasa tertarik dan ingin melakukan penelitian mengenai pengaruh $\mathrm{pH}$ dan kapasitas buffer saliva terhadap pembentukan kalkulus.

\section{BAHAN DAN METODE}

Penelitian ini adalah penelitian analitik observasional dengan rancangan penelitian cross section-nal. Sampel penelitian ini adalah 40 pasien yang datang berkunjung ke Instalasi Periodonsia Rumah Sakit Gigi dan Mulut Universitas Sumatera Utara. Seluruh sampel pada penelitian ini harus memenuhi kriteria inklusi: berusia 18-60 tahun, sehat secara sistemik dan bersedia berpartisipasi dalam penelitian dan kriteria ekslusi: subjek yang mengonsumsi obat sistemik, hamil, perokok berat, pecandu alkohol, pemakai pesawat ortodonti dan pasien yang mengonsumsi asam 2 jam terakhir.

Penelitian dilakukan setelah mendapatkan persetujuan dari Komisi Etik USU (Health Research Ethical Committee of North Sumatera). Untuk memperoleh identitas dan riwayat medis responden dilakukan wawancara dengan bantuan kuesioner, selain itu responden juga diminta untuk menandatangani informed consent. Setelah itu, responden diminta untuk mengumpulkan saliva yang distimulasi dengan permen karet wax selama 5 menit 30 detik dan kemudian dilakukan pemeriksaan kalkulus dengan menggunakan Volpe Manhold Index 
(VMI) dan Oral Calculus Index Simplified (OCIS), dan dilakukan pemeriksaan jaringan periodontal dengan Periodontal Disease Index (PDI). Kemudian, dilakukan pengukuran $\mathrm{pH}$ serta kapasitas buffer dari saliva yang telah dikumpulkan menggunakan $\mathrm{pH}$ meter dan GC Buffer test strip. Analisis data dilakukan dengan uji Kolmogorov-Smirnov untuk melihat apakah data yang didapat dari hasil penelitian terdistribusi dengan normal dan uji korelasi Pearson untuk melihat pengaruh $\mathrm{pH}$ dan kapasitas buffer saliva terhadap pembentukan kalkulus.

\section{HASIL}

Tabel 1. Skor PDI, OCIS dan VMI pada keseluruh-an responden $(n=40)$

\begin{tabular}{lcc}
\hline \multicolumn{1}{c}{ Variabel } & Jumlah & $\%$ \\
\hline Periodontal Disease Index & & \\
$\quad$ Normal & 6 & 15 \\
Gingivitis & 32 & 80 \\
$\quad$ Periodontitis & 2 & 5 \\
Oral Calculus Index Simplified & & \\
$\quad$ Baik & 17 & 42,5 \\
Sedang & 20 & 50 \\
Buruk & 3 & 7,5 \\
Volpe Manhold Index & & \\
Tidak ada pembentukan kalkulus & 4 & 10 \\
Pembentukan kalkulus ringan & 32 & 80 \\
Pembentukan kalkulus berat & 4 & 10 \\
\hline
\end{tabular}

Tabel 2. Nilai $\mathrm{pH}$ dan kapasitas buffer saliva distimulasi dari keseluruhan responden (n-40)

\begin{tabular}{lcc}
\hline \multicolumn{1}{c}{ Variabel } & Jumlah & $\%$ \\
\hline pH saliva & & \\
Saliva bersifat asam & 0 & 0 \\
Saliva normal & 9 & 22,5 \\
Saliva bersifat alkali & 31 & 77,5 \\
Kapasitas buffer saliva & & \\
Sangat rendah & 3 & 7,5 \\
Rendah & 21 & 52,5 \\
Normal & 16 & 40 \\
\hline
\end{tabular}

Tabel 3. Nilai pH dan kapasitas buffer saliva distimulasi keseluruhan subyek dengan Oral Calculus Index Simplified

\begin{tabular}{lcc}
\hline \multicolumn{1}{c}{ Variabel } & $\mathrm{r}$ & Hasil uji statistik \\
\hline pH saliva & 0,519 & $0,001^{*}$ \\
Kapasitas buffer saliva & 0,488 & $0,001^{*}$ \\
\hline *signifikan $\mathrm{p}<0,05$ & &
\end{tabular}

Tabel 4. Nilai $\mathrm{pH}$ dan kapasitas buffer saliva distimulasi keseluruhan subjek dengan Volpe Manhold Index

\begin{tabular}{lcc}
\hline \multicolumn{1}{c}{ Variabel } & $\mathrm{r}$ & Hasil uji statistik \\
\hline pH saliva & 0,658 & $0,000^{*}$ \\
Kapasitas buffer saliva & 0,604 & $0,000^{*}$ \\
\hline *signifikan $\mathrm{p}<0,05$ & &
\end{tabular}

Tabel 5. Nilai $\mathrm{pH}$ dan kapasitas buffer saliva distimulasi keseluruhan subjek dengan Periodontal Disease Index

\begin{tabular}{lcc}
\hline \multicolumn{1}{c}{ Variabel } & $\mathrm{r}$ & Hasil uji statistik \\
\hline pH saliva & 0,421 & $0,007 *$ \\
Kapasitas buffer saliva & 0,472 & $0,002^{*}$ \\
\hline
\end{tabular}

*signifikan $\mathrm{p}<0,05$

\section{PEMBAHASAN}

Hasil penelitian menunjukkan nilai korelasi signifikansi yang mutlak yaitu hubungan yang kuat antara $\mathrm{pH}$ dan kapasitas buffer saliva dengan penumpukan kalkulus yang dinilai melalui OCIS dan VMI. Hasil penelitian ini menunjukkan bahwa peningkatan $\mathrm{pH}$ dan kapasitas buffer saliva secara signifikan diikuti dengan peningkatan skor OCIS dan VMI. Hal ini sesuai dengan penelitian yang dilakukan oleh Gupta dkk. Davidovich dkk. dan Wong dkk. $15,19,20$

Hasil penelitian ini juga menunjukkan korelasi positif yang signifikan dengan hubungan yang moderat $\mathrm{pH}$ dan kapasitas buffer saliva terhadap keadaan jaringan periodontal yang dinilai melalui PDI secara umum. Hal ini menunjukkan kenaikan $\mathrm{pH}$ dan kapasitas buffer saliva diikuti dengan kenaikan skor PDI. Hasil penelitian ini sesuai dengan penelitian Mashhadani dan Hinrichs. ${ }^{1,11}$

$\mathrm{pH}$ saliva pasien yang tinggi dapat mendukung pembentukan kalkulus dengan cara meningkatkan kejenuhan komponen kalkulus pada plak gigi. ${ }^{21} \mathrm{Pe}-$ nelitian sebelumnya juga menunjukkan bahwa $\mathrm{pH}$ yang bersifat basa sangat penting untuk deposisi kalsium fosfat yang dapat mendukung mineralisasi plak sehingga terbentuk kalkulus. ${ }^{16}$ Semua bentuk kandungan mineral kalkulus bersifat larut dalam keadaan $\mathrm{pH}$ yang rendah dibandingkan dengan keadaan $\mathrm{pH}$ yang lebih tinggi. Ketika keadaan $\mathrm{pH}$ berada diatas nilai kritis, $\mathrm{pH}$ akan mengalami kejenuhan karena hidroksiapatit sehingga meningkatkan kecenderungan deposit kalkulus dan remineralisasi lesi white spot enamel. Oleh sebab itu, pembentukan kalkulus lebih dapat terjadi ketika $\mathrm{pH}$ bertahan pada keadaan diatas $\mathrm{pH}$ kritis dalam jangka waktu yang lama. ${ }^{21}$

Kapasitas buffer saliva yang tinggi dapat mendukung pembentukan kalkulus dengan cara mempertahankan nilai $\mathrm{pH}$ tetap berada di atas nilai $\mathrm{pH}$ kritis yang mendukung kejenuhan hidroksiapatit pada plak gigi. Kapasitas buffer saliva ini sangat berhubungan erat dengan $\mathrm{pH}$ saliva dimana kapasitas buffer ini memegang peranan penting dalam pemeliharaan $\mathrm{pH}$ saliva. ${ }^{22}$

Sebagai kesimpulan, $\mathrm{pH}$ dan kapasitas buffer saliva berpengaruh secara signifikan terhadap pem- 
bentukan kalkulus dan indeks periodontal sehingga individu dengan $\mathrm{pH}$ dan kapasitas buffer saliva yang tinggi diharapkan lebih memperhatikan kesehatan rongga mulutnya. Selain itu, saliva juga diharapkan dapat menjadi salah satu media diagnostik untuk pemeriksaan jaringan periodontal.

\section{Daftar Pustaka}

1. Hinrichs JE. The role of dental calculus and other local predisposing factors. In: Carranza FA ed. Carranza's Clinical Periodontology. $11^{\text {th }}$ ed., Missouri: Elsevier, 2012: 217-22.

2. Chung WO, An JY. Periodontal diseases and gingival innate immunity-who has the upper hand? In: Manakil J. ed. Periodontal diseases-a clinician's guide. Croatia: Intech 2012: 3, 7, 70-1.

3. Ryan ME. Nonsurgical Approaches for the Treatment of periodontal diseases. Dent Clin North Am 2005; 49: 611.

4. Gu Y, Ryan ME. Overview of periodontal diseases and overall health: a clinician's guide. USA: the Colgate-Palmolive Company, 2010: 5-15.

5. Carneiro LC, Kabulwa MN. Dental caries, and supragingival plaque and calculus among students, Tanga, Tanzania. ISRN Dentistry 2012; 1-6.

6. Eke PI, Dye BA, Wei L, Thornton-evans GO, Genco RJ. Prevalence of periodontitis in adults in United States: 2009 and 2010. J Dent Res 2012; 91(10): 914-20.

7. Wahyukundari MA. Perbedaan kadar matrix mettaloproteinase-8 setelah scalling dan pemberian tetrasiklin pada penderita periodontitis kronis. J PDGI 2009; 58: 1-6.

8. Saptorini KK. Poket periodontal pada lanjut usia di posyandu lansia kelurahan Wonosari kota Semarang. Dalam: Peran kesehatan masyarakat dalam pencapaian MDG's di Indonesia. Prosiding Seminar Nasional, 2011: 261-6.

9. Dumitrescu AL, Kobayashi J. Genetic variants in periodontal health and disease. German: Springerverlag Berlin Heidelberg, 2010: 1-14.

10. Walsh LJ. Clinical aspects of salivary biology for the dental clinician. J Minim Interv dent 2008; 1(1): 7-24.

11. Al-Mashhadani AT, Al-obaidi WA. The $\mathrm{pH}$ of stimulated saliva in relation to oral health status among children and adults. J College Dentistry 2005; 17(1): 89-91.

12. Fabian TK, Fejerdy P, Csermely P. Saliva in health and disease, chemical biology of. Wiley Encyclopedia of chemical biology 2007: 1-9.

13. Wu KP, Ke JY, Chung CY, Chen CL, Hwang TL, Chou MY. Relationship between unstimulated salivary flow rate and saliva composition of healthy children in Taiwan. Chang Gung Med J 2008; 31(3): 281-5.

14. Arabaci T, Cicek Y, Beydemir S, Canakci CF, Canakci V. Are increased salivary carbonic anhydrase VI levels related to the amount of supragingival dental calculus formation and clinical periodontal scores?. J Dent Sciences 2013:1-5.

15. Gupta S, Bhat KM, Kumar MSA. Influence of oral hygiene measures, salivary $\mathrm{pH}$ and urea level on calculus formation - A clinical study. J Indian Dental Association 2011; 5(5): Abstract.

16. Ramisetti A, Babu R, Kotha K, Tej G, Chirtha S. Influence of salivary $\mathrm{pH}$ and urea level on calculus formation-clinical study. Carib J Scitech 2014; 2: 503-8.

17. Kitasako Y, Ikeda M, Burrow MF, Tagami J. Oral health status in relation to stimulated saliva buffering capacity among Japanese adults above or below 35 years of age. J Med Dent Sci 2006; 53 : 175-80.

18. Gopinath VK, Arzreanne AR. Saliva as a diagnostic tool for assessment of dental caries. Archives of Orofacial Sciences 2006; 1: 57-9.

19. Davidovich E, Davidovits M, Peretz B, Shapira J, Aframian DJ. The correlation between dental calculus and disturbed mineral metabolism in paediatric patients with chronic kidney disease. Nephrol Dial Transplant 2009; 24: 2439-45.

20. Wong L, Sissons CH, Pearce EI, Cutress TW. Calcium phosphate deposition in human dental plaque microcosm biofilms induced by an ureolytic pH rise procedure: Arch Oral Biol 2002: 47(11): Abstract.

21. Dawes C. Why does supragingival calculus form preferentially on the lingual surface of the 6 lower anterior teeth?. JCDA 2006-7; 72(10): 923-6.

22. Naveen S, Asha M, Shubha G, Bajoria AA, Jose AA. Salivary flow rate, $\mathrm{pH}$ and buffering capacity in pregnant and non pregnant women-A comparative study. JMED research 2014: 1-8. 